Acta Agroph., 2019, 26(3), 65-76

doi: $10.31545 /$ aagr/116407

\title{
OPTIMISATION OF THINNING OF APPLE FRUITLETS CV. 'BRAEBURN MARIRI RED'
}

\author{
Iwona Szot@, Tomasz Lipa \\ Institute of Horticultural Production, University of Life Sciences in Lublin \\ Głęboka 28, Lublin, Poland \\ e-mail: szoti@autograf.pl
}

\begin{abstract}
Apple blossom or fruitlet thinning is currently the basic care treatment in the production of apples for dessert fruit. It determines the regularity, levels and quality of yields. The fastest method of fruitlet thinning is chemical thinning performed by means of registered purpose-developed preparations. The response of apple trees to chemical thinning is largely dependent on the genetic traits and on the physiological status of the tree, and on the climatic conditions in a given season. Braeburn, and especially its coloured mutations, e.g. Braeburn Mariri Red, is a prospective cultivar for cultivation in Poland, as it stores well without loss of firmness. In addition it is characterised by more sour flesh taste compared to popular apples of cultivars 'Golden Delicious', 'Gala' or 'Jonagold', due to which it can be in demand in periods when apples of cv. 'Antonówka' are no longer available. The study analysed the effect of the Polish-registered preparations Brevis $150 \mathrm{SG}$ and MaxCel on the level and quality of yield of cultivar 'Braeburn Mariri Red'. Each of the methods of thinning caused a significant improvement of fruit size relative to the control. Only the application of MaxCel at the lower dose of $51 \mathrm{ha}^{-1}$ proved to be completely ineffective in both seasons of the experiment due to the lack of any improvement in yield structure, in fruit weight, and also in fruit diameter and height. The application of Brevis at $1.1 \mathrm{~kg} \mathrm{ha}^{-1}$ and of MaxCel at $7.51 \mathrm{ha}^{-1}$ produced similar effects on the level and structure of yield, but apples from trees treated with Brevis at $1.1 \mathrm{~kg} \mathrm{ha}^{-1}$ were characterised by notably higher fresh firmness. The best effects of thinning were noted after the combined application of the preparations MaxCel/Brevis, as the yield was notably lower than in the control treatment, and the fruits were characterised by the highest values of the analysed quality parameters, i.e. fruit weight, diameter, height, and content of extract and dry matter.
\end{abstract}

Keyw ords: crop load, fruit quality, metamitron, benzyladenine

\section{INTRODUCTION}

Poland is a leading producer of apple in the EU, as since 2011 it ranks the $1^{\text {st }}$ in terms of yields (http://www.wapa-association.org/docs/2019/European_summary_reduced.pdf.). Production of about 4 million tons of apples vastly exceeds the 
demand of the local market, making exports a necessity. High consumer requirements concerning apple quality stimulate the producers to apply ever newer and more effective cultivation technologies. The basic treatment that determines annual yields of apples of suitable quality is the thinning of apple blossom or fruitlets. The thinning can be performed by hand or chemically. The effectiveness of chemical thinning depends to a high extent on the kind of preparation used, on the climatic conditions, and on the response of apple cultivars (Link 2000).

In Poland the use of chemical preparations for apple fruitlet thinning is subject to legislative regulation, and they have to be approved and registered as plant protection agents. At present, preparations based on cytokinins and metamitron are approved for application in apple orchards. Preparations with cytokinins in their composition have been in use for the control of fruit tree crop load for a long time now. Cytokinins are highly important phytohormones, synthesised in the roots, involved primarily in cell division and in the processes of senescence. Cytokinins, in the form of 6-benzyladenine, were introduced as chemical thinners in the nineteen eighties (McLaughlin and Greene 1984). It was observed that BA (benzyladenine) increases fruit mass not only through a reduction of yield (Elfving and Cline 1993, Ferree 1996), but also has a direct impact (Greene 1993, 2005) on increased fruit size through stimulation and intensification of cell division in growing fruits (Wismer and Proctor 1995).

The preparation Brevis contains metamitron which is an inhibitor of photosynthesis. Photosynthesis occurs in two stages - light (light-dependent reactions) and dark (light-independent reactions). The light-dependent reactions take place in the chloroplast thylakoids, which contain light-absorbing pigments and two centres of light energy transformation into chemical energy, referred to as photosystem II (PS II) and photosystem I (PS I). The result of the processes taking place during the light stage is the formation of ATP and NADPH which are then used in the dark stage of photosynthesis. Metamitron, affecting the process of photosynthesis, blocks the transport of electrons through photosystem II, which results in accumulation of energy and consequent degradation of chlorophyll and carotenoids. It can also inhibit photosynthetic phosphorylation and electron acceptance. Metamitron disturbs electron transport in PS II, inhibiting the transformation of light energy into chemical energy. This has an impact on fruit setting and growth, as a result of affecting the level (reserve) of carbohydrates in the plant. It works in conformance with the hypothesis that carbohydrate deficit in fruits is one of the first symptoms of susceptibility to fruit shedding or fruit keeping (McArtney and Obermiller 2014). 
Russia's ban on Polish apples caused the necessity of change in the structure of apple cultivars. Highly popular in countries of Western Europe is the cultivar Braeburn whose fruits, after being taken out of cold storage, maintain high quality for a very long time. Apple tree cv. 'Braeburn Mariri Red' is a French mutation of 'Braeburn', isolated due to its better colouring of the skin.

The aim of the experiment presented here was to determine the optimum method of thinning of fruitlets of apple tree cv. 'Braeburn Mariri Red' with the use of the chemical thinners Brevis 150 SG and MaxCel.

\section{MATERIAL AND METHOD}

The experiment was conducted in the years 2016-2017. The experimental material consisted of six- and seven-year old trees of the cultivar 'Braeburn Mariri Red'/M.9 T337, growing in a private orchard in the locality of Stryjno. The trees were planted in rows oriented in the north-south direction, with spacing of $3.0 \times 0.8 \mathrm{~m}$. The protection of the trees against pests was applied at conformance with current recommendations for production orchards. Fertilisation was applied following the YARA program. For each of the methods of thinning 10 trees were used, with uniform growth intensity and similarly abundant blossom in 2016. The experimental trees were selected at random along the rows. Thinning was performed using the preparations Brevis $150 \mathrm{SG}$ and MaxCel, approved and registered in Poland, individually or in a mixture.

Brevis $150 \mathrm{SG}$ contains metamitron (a compound from the group of triazines) at $150 \mathrm{~g} \mathrm{~kg}^{-1}(15 \%)$. It is produced in the form of water-soluble granules, for use as a thinner for apple and pear trees. It is the most effective at temperature of $10-25^{\circ} \mathrm{C}$, and its effect is stronger in the shade, after sunset or under anti-hail protective netting.

MaxCel is a preparation containing 6-benzyladenine at $20 \mathrm{~g} \mathrm{l}^{-1}(1.9 \%)$, amended with a surfactant allowing better absorption of active substance. It occurs in liquid form, and it is recommended to apply at temperature $>15^{\circ} \mathrm{C}$ (optimum $20-25^{\circ} \mathrm{C}$ ), assuming the temperature remains stable for 2-3 days after the application.

The chemical thinning treatments were performed on the $28^{\text {th }}$ of May in 2016 and on the $26^{\text {th }}$ of May in 2017 (Figs 1 and 2), as follows:

- Control treatment (no thinning);

- Thinning by hand (after fruitlet dropping);

- Brevis $1.1 \mathrm{~kg}$; (1000 1 water ha $\left.{ }^{-1}\right)$, at central fruitlet diameter of $10-12 \mathrm{~mm}$;

- MaxCel $51 \mathrm{ha}^{-1}$; (1000 1 water ha-1), at central fruitlet diameter of 10-12 mm;

- MaxCel $7.51 \mathrm{ha}^{-1}$; (1000 1 water ha $\left.{ }^{-1}\right)$, at central fruitlet diameter of 10-12 mm;

- MaxCel $51 \mathrm{ha}^{-1}+\operatorname{Brevis}\left(1.1 \mathrm{~kg} \mathrm{ha}^{-1} ; 10001\right.$ water ha $\left.{ }^{-1}\right)$, at central fruitlet diameter on older wood of $10-12 \mathrm{~mm}$. 


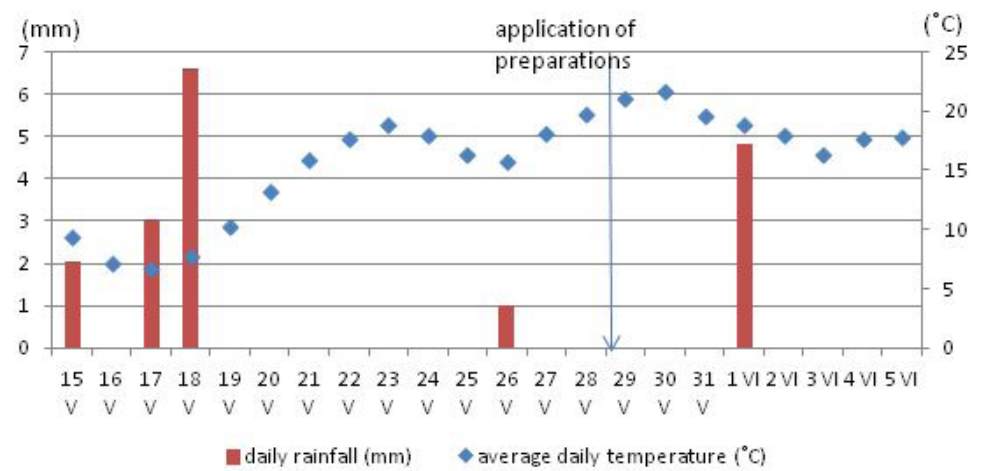

Fig. 1. Weather conditions in the period before, during and after thinning treatments in 2016

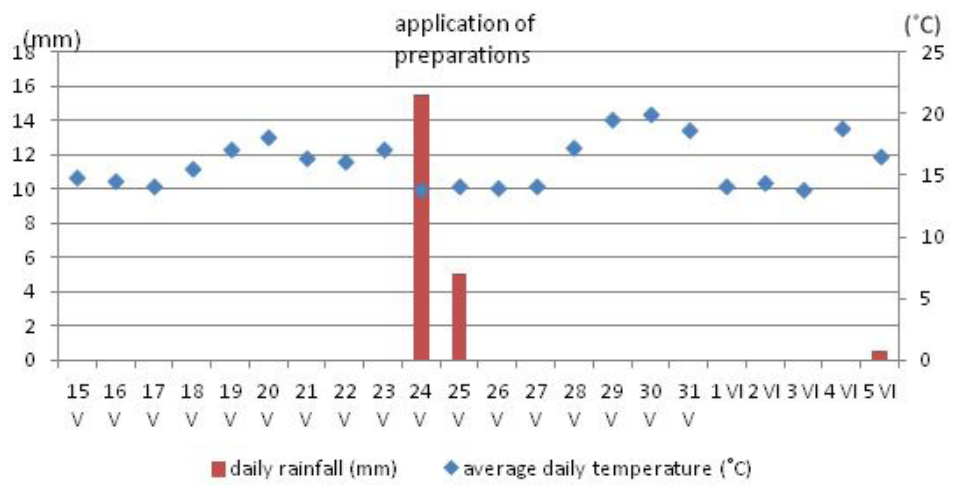

Fig. 2. Weather conditions in the period before, during and after thinning treatments in 2017

Apple harvest was conducted on the $21^{\text {st }}$ of October in 2016, and on the $20^{\text {th }}$ of October in 2017, separately for each tree, and total yield was determined in the number of apples and in $\mathrm{kg}_{\text {tre }}{ }^{-1}$. At the moment of the harvest, 100 fruits were taken from each of the thinning treatments, and the share of fruits from the individual size classes was determined. Other determinations included the following:

- mass of a single fruit (g), by means on an electronic balance;

- fruit diameter and height, using an electronic caliper;

- fruit colouring, in 1-5 scale, on twenty fruits, where $1-0 \% ; 2-1-25 \%, 3-26$ $50 \% ; 4-51-75 \%$ and $5-76-100 \%$ of the fruits covered with skin blush;

- flesh firmness of the fruits $\left(\mathrm{kG} \mathrm{cm}^{-2}\right)$, on twenty fruits - measurement taken on fruits with and without blush using the Magness-Taylor firmness tester;

- extract content in the fruits (\%), on twenty fruits, using the Abbe refractometer;

- dry matter content (\%), with the over-dry method, in three replicates. 
The results were processed statistically using the method of the analysis of variance. Significance of differences was determined using the Tukey test at significance of $5 \%$, in the program STATISTICA for Windows ver. 5.5A.

\section{RESULTS AND DISCUSSION}

In 2016, each of the methods of thinning, apart from thinning by hand, caused a significant reduction of yield (pcs/ha) in relation to the control treatment (Tab. 1). The highest effect of thinning was noted for the combination MaxCel/Brevis. In the following season, no significant differences in the yield were content relative to the control. Based on the mean value for the two years it was demonstrated that thinning with the use of the preparations MaxCel/Brevis caused a significant reduction of yield expressed as pcs/tree relative to the control.

Table 1. Effect of various methods of thinning on total yield expressed in pcs/tree and $\mathrm{kg} / \mathrm{tree}$

\begin{tabular}{lcccccc}
\hline & \multicolumn{3}{c}{ total yield in pcs/tree } & \multicolumn{2}{c}{ total yield in kg/tree } \\
\cline { 2 - 6 } & 2016 & 2017 & $\begin{array}{c}\text { mean for two } \\
\text { years }\end{array}$ & 2016 & 2017 & $\begin{array}{c}\text { mean for two } \\
\text { years }\end{array}$ \\
\hline Control & $123.0 \mathrm{~d}^{*}$ & $148.3 \mathrm{a}$ & $135.7 \mathrm{~b}$ & $22.4 \mathrm{bc}$ & $22.0 \mathrm{a}$ & $22.2 \mathrm{~b}$ \\
Thinning by hand & $111.8 \mathrm{~cd}$ & $132.6 \mathrm{a}$ & $122.2 \mathrm{ab}$ & $24.2 \mathrm{c}$ & $17.6 \mathrm{a}$ & $20.9 \mathrm{ab}$ \\
Brevis 1.1 kg & $77.2 \mathrm{ab}$ & $135.0 \mathrm{a}$ & $106.1 \mathrm{ab}$ & $17.7 \mathrm{ab}$ & $18.2 \mathrm{a}$ & $18.0 \mathrm{a}$ \\
MaxCel 5 1 & $94.4 \mathrm{bc}$ & $149.8 \mathrm{a}$ & $122.1 \mathrm{ab}$ & $16.9 \mathrm{ab}$ & $22.4 \mathrm{~b}$ & $19.7 \mathrm{ab}$ \\
MaxCel 7.5 1 & $83.0 \mathrm{ab}$ & $141.2 \mathrm{a}$ & $112.1 \mathrm{ab}$ & $18.7 \mathrm{a}-\mathrm{c}$ & $19.9 \mathrm{ab}$ & $19.3 \mathrm{ab}$ \\
MaxCel/Brevis & $58.2 \mathrm{a}$ & $143.0 \mathrm{a}$ & $100.6 \mathrm{a}$ & $15.0 \mathrm{a}$ & $20.4 \mathrm{ab}$ & $17.7 \mathrm{a}$ \\
Mean for the year & $91.27 \mathrm{~A}^{* *}$ & $141.65 \mathrm{~B}$ & & $19.15 \mathrm{~A}$ & $20.10 \mathrm{~A}$ & \\
\hline
\end{tabular}

*mean values in a column, denoted with the same lower-case letter, do not differ statistically at significance level $\mathrm{P}<0.05$ : ** mean values in a line, relating to a given parameter, denoted with the same capital letter, do not differ statistically at significance level $\mathrm{P}<0.05$.

Estimating the effect of the various thinning methods on total yield expressed in $\mathrm{kg}$ tree ${ }^{-1}$, it was noted that in 2016 only trees treated with the preparations $\mathrm{MaxCel} /$ Brevis produced considerably lower yields than the control trees. In the subsequent season of the experiment no significant differences in the value of that parameter were noted relative to the control, apart from the treatment MaxCel 51 , where the mass of the yield was significantly higher. Based on the mean value for the two years, it was noted that thinning caused a reduction of yield expressed in $\mathrm{kg}$ tre $\mathrm{e}^{-1}$, but only after the treatment with the preparations MaxCel/Brevis that reduction was significant, relative to the control.

The mean total yield expressed in pcs/tree was notably lower in 2016 than in the following year, but the difference in mass yield was not significant. The very clear response of the trees to chemical thinning in the first season of the experiment may be a result of more favourable temperature conditions during the treatment application (Fig. 1). It is common knowledge that climatic conditions, and especially the temperature, have an impact on the effectiveness of thinning with the use 
of BA (Williams 1994, Greene 2002) and that cytokinins require high temperatures (Bound et al. 1997). Byers (2002) emphasised that in the conditions of strong cloud cover and high temperature excessive thinning is often observed after the application of chemical thinners. Whereas, the same preparations applied at strong cloud cover but at low temperatures are considerably less effective. Olien and Bukovac (1978) demonstrated that lower temperatures can inhibit or delay the effect of hormones due to an unsuitable level of metabolic transformations in the plant. In such conditions the effectiveness of the preparations is reduced, and determines the formation of a barrier layer between the fruitlet petiole and the shoot. In addition, one can suppose that after a year of poorer yielding the trees produced higher quality flower buds which set stronger fruitlets, less susceptible to the preparations applied, especially at too low air temperature.

The yield structure in 2016 improved after the application of the thinning treatments, with the exception of MaxCel 51 , where the percentage of fruits with diameter smaller than $65 \mathrm{~mm}$ increased relative to the control. In the remaining treatments the share of fruits with diameters greater than $75 \mathrm{~mm}$ was higher than $71 \%$ (Fig. 3). In 2017 none of the thinning methods eliminated fruits with diameters smaller than $65 \mathrm{~mm}$ from the yield. The best yield structure was noted after thinning by hand, where the share of fruits with diameters above $75 \mathrm{~mm}$ increased to $26 \%$ (Fig. 4). In 2016, the yield structure and the quality traits of fruits, such as the mass of a single fruit, fruit size (diameter, height), attained higher values even though the yield expressed in $\mathrm{kg}_{\text {tree }}{ }^{-1}$ was similar in both years of the study. This results from the fact that in 2016 the trees were loaded with a considerably smaller number of fruits than in 2017. Increase in the number of fruits often caused a deterioration of yield structure and smaller mass of a single fruit at the time of harvest (Palmer et al. 1997, Wünsche et al. 2000, Wünsche and Ferguson 2005, de Salvador et al. 2006). Palmer et al. (1997) demonstrated that apple trees cv. 'Braeburn'/M26, a lower-yielding cultivar, produced apples of higher quality, i.e. with better colouring, and higher content of extract and dry matter. They noted that a strong yield delayed fruit ripening and had a negative effect on the content of sugars and acids, and on flesh firmness. In the experiment presented here, apples from trees with smaller number of fruits (in 2016) had larger dimensions, but in terms of dry matter content and firmness they showed lower values than those from trees that produced higher yields in 2017. One can assume that the trees, after a season of poor fruition, produced buds of high quality which formed fruits with high quality parameters as regards flesh firmness and dry matter content. Schwabe (1978) demonstrated that a high yield of apple trees caused notably poorer blossom in the following year, and the formed buds were distinctly smaller than after a year of poor yields. Buszard and Schwabe (1995) compared the quality of flowers of apple trees cv. 'Koksa Pomarańczowa' after years of abundant and poor yields and concluded that flowers 
from trees on which strong thinning was applied were characterised in the following season by greater ability of fruit setting. This resulted from their better quality, consisting in better developed carper stigma and bigger stamens.

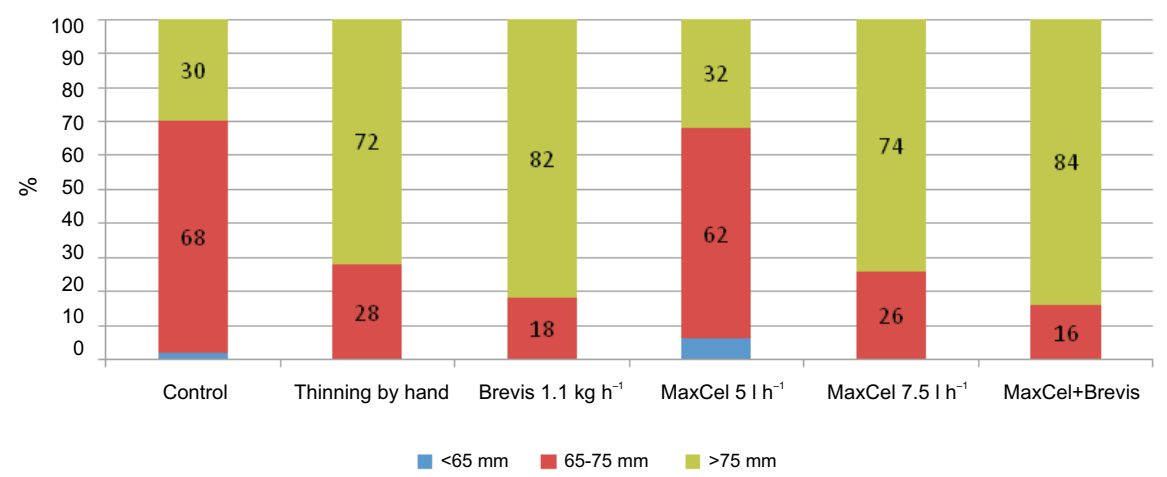

Fig. 3. Yield structure of apple tree cv. 'Braeburn Mariri Red' in 2016

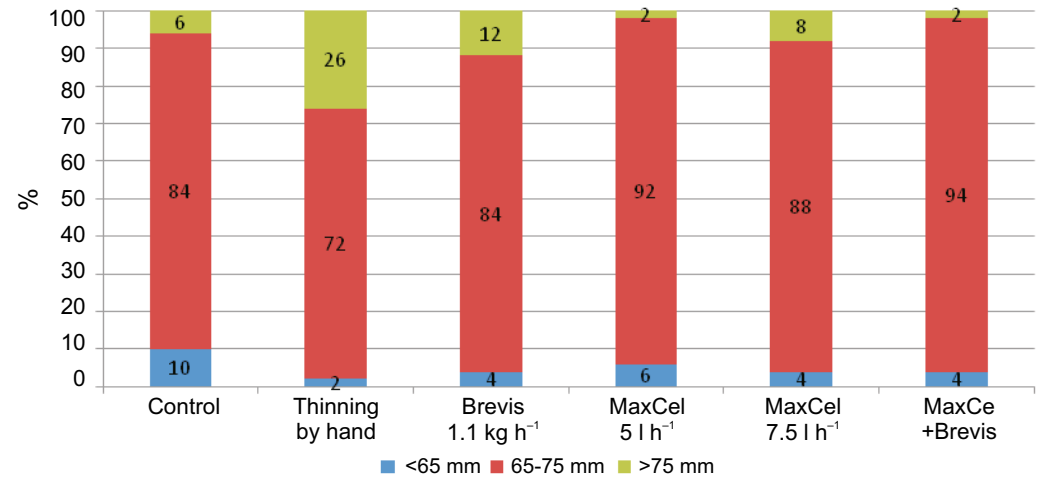

Fig. 4. Yield structure of apple tree cv. 'Braeburn Mariri Red' in 2017

In 2016, most of the methods of thinning caused a considerable increase in apple mass relative to the control fruits, with the exception of treatment $\mathrm{MaxCel}$ 51 (Tab. 2). In the following season of the experiment, a significant increase in the value of the trait in question was noted only after thinning by hand. Based on the mean values from the two years, one can note that each method of thinning caused an increase of fruit mass, except for the treatment MaxCel 51.

In 2016, each method of thinning, except for MaxCel 51 , caused a significant increase of apple diameter relative to the control. In the following season, apples from trees subjected to thinning also had a notably larger diameter than control fruits, except for the application of MaxCel/Brevis. Based on the mean values for the two years, a significant increase of that parameter was noted following each of the thinning methods, except for the treatment MaxCel 51. 
Table 2. Effect of various methods of thinning on external quality parameters of apples cv. 'Braeburn Mariri Red'

\begin{tabular}{|c|c|c|c|c|c|c|c|}
\hline & Control & $\begin{array}{l}\text { Thinning } \\
\text { by hand }\end{array}$ & $\begin{array}{l}\text { Brevis } \\
1.1 \mathrm{~kg}\end{array}$ & $\begin{array}{c}\text { MaxCel } \\
51 \\
\end{array}$ & $\begin{array}{c}\text { MaxCel } \\
7.51 \\
\end{array}$ & $\begin{array}{l}\text { MaxCel } \\
+ \text { Brevis }\end{array}$ & $\begin{array}{c}\text { Mean for } \\
\text { a year }\end{array}$ \\
\hline $\begin{array}{l}\text { mass of a single fruit }(\mathrm{g}) \\
2016\end{array}$ & $181.87 \mathrm{a}^{*}$ & $216.27 \mathrm{~b}$ & $229.49 \mathrm{~b}$ & $179.31 \mathrm{a}$ & $225.75 \mathrm{~b}$ & $257.27 \mathrm{c}$ & $214.99 \mathrm{~B}^{* *}$ \\
\hline $\begin{array}{l}\text { mass of a single fruit }(\mathrm{g}) \\
2017\end{array}$ & $152.53 \mathrm{a}$ & $169.34 \mathrm{~b}$ & $162.04 \mathrm{ab}$ & $154.79 \mathrm{a}$ & $156.44 \mathrm{ab}$ & $157.36 \mathrm{ab}$ & $158.75 \mathrm{~A}$ \\
\hline $\begin{array}{l}\text { mass of a single fruit } \\
\text { (mean for two years) }\end{array}$ & $167.20 \mathrm{a}$ & $192.80 \mathrm{~b}$ & $195.76 \mathrm{~b}$ & $167.05 \mathrm{a}$ & $191.09 \mathrm{~b}$ & $207.31 \mathrm{~b}$ & \\
\hline $\begin{array}{l}\text { fruit diameter in } 2016 \\
(\mathrm{~mm})\end{array}$ & $69.32 \mathrm{a}$ & $74.34 \mathrm{~b}$ & $75.26 \mathrm{~b}$ & $70.81 \mathrm{a}$ & $75.39 \mathrm{~b}$ & $75.85 \mathrm{~b}$ & $73.49 \mathrm{~B}$ \\
\hline $\begin{array}{l}\text { fruit diameter in } 2017 \\
(\mathrm{~mm})\end{array}$ & $70.43 \mathrm{a}$ & $71.41 \mathrm{~b}$ & $71.44 \mathrm{~b}$ & $71.50 \mathrm{~b}$ & $71.34 \mathrm{~b}$ & $70.95 \mathrm{ab}$ & $71.18 \mathrm{~A}$ \\
\hline $\begin{array}{l}\text { fruit diameter } \\
\text { (mean for two years) }\end{array}$ & $69.87 \mathrm{a}$ & $72.87 \mathrm{~b}$ & $73.35 \mathrm{~b}$ & $71.15 \mathrm{a}$ & $73.37 \mathrm{~b}$ & $73.40 \mathrm{~b}$ & \\
\hline $\begin{array}{l}\text { fruit height in } 2016 \\
(\mathrm{~mm})\end{array}$ & $70.57 \mathrm{a}$ & $76.16 \mathrm{~b}$ & $77.72 \mathrm{bc}$ & $70.52 \mathrm{a}$ & $75.09 \mathrm{ab}$ & $81.37 \mathrm{c}$ & $75.24 \mathrm{~B}$ \\
\hline $\begin{array}{l}\text { fruit height in } 2017 \\
(\mathrm{~mm})\end{array}$ & $66.20 \mathrm{a}$ & $67.58 \mathrm{~b}$ & $66.29 \mathrm{a}$ & $66.96 \mathrm{ab}$ & $67.02 \mathrm{ab}$ & $67.36 \mathrm{ab}$ & $66.90 \mathrm{~A}$ \\
\hline $\begin{array}{l}\text { fruit height } \\
\text { (mean for two years) }\end{array}$ & $68.39 \mathrm{a}$ & $71.87 \mathrm{ab}$ & $72.01 \mathrm{ab}$ & $68.74 \mathrm{a}$ & $71.05 \mathrm{ab}$ & $74.37 \mathrm{~b}$ & \\
\hline $\begin{array}{l}\text { fruit colouring in } 2016 \\
(1-5 \text { scale })\end{array}$ & $4.96 \mathrm{ab}$ & $4.92 \mathrm{ab}$ & $4.96 \mathrm{ab}$ & $5.00 \mathrm{~b}$ & $4.72 \mathrm{a}$ & $4.80 \mathrm{ab}$ & $4.89 \mathrm{~A}$ \\
\hline $\begin{array}{l}\text { fruit colouring in } 2017 \\
(1-5 \text { scale })\end{array}$ & $4.92 \mathrm{c}$ & $4.92 \mathrm{c}$ & $4.68 \mathrm{a}$ & $4.96 \mathrm{c}$ & $4.84 \mathrm{bc}$ & $4.72 \mathrm{ab}$ & $4.84 \mathrm{~A}$ \\
\hline $\begin{array}{l}\text { fruit colouring } \\
\text { (mean for two years) }\end{array}$ & $4.94 \mathrm{ab}$ & $4.92 \mathrm{ab}$ & $4.82 \mathrm{ab}$ & $4.98 \mathrm{~b}$ & $4.78 \mathrm{ab}$ & $4.76 \mathrm{a}$ & \\
\hline
\end{tabular}

*mean values in a column, denoted with the same lower-case letter, do not differ statistically at significance level $\mathrm{P}<0.05 ; * *$ mean values in a line, relating to a given parameter, denoted with the same capital letter, do not differ statistically at significance level $\mathrm{P}<0.05$.

In certain experiments (Bubán 2000), an elongation effect on apple was noted after the application of cytokinins. However, in this experiment the one-time application of MaxCel did not produce such an effect. Estimating the height of apples in 2016 it was observed that the treatments with thinning by hand, Brevis $1.1 \mathrm{~kg}$ and $\mathrm{MaxCel} /$ Brevis caused a significant increase in the value of that parameter. In the second year of the study only the treatment with thinning by hand caused a significant increase of apple height. Mean values for the two years indicate that only the application of MaxCel/Brevis caused a significant increase of fruit height relative to the control. Decrease of the number of fruits is usually correlated with increase of apple size. According to Meland (2009), decrease of the number of fruits on a tree as a result of thinning caused an increase of leaf area per fruit, and thus improved the accessibility of assimilates to the remaining fruits.

Apple skin colouring is one of the factors that determine market acceptance. Red colour depends on the amount of anthocyanins accumulated in the skin, and is largely related to genetic traits, weather and habitat conditions, fertilisation, and also the degree of maturity of fruits (Telias et al. 2011). Usually, consumers prefer apples with stronger colouring, so apple producers seek ways of improving the value of that 
parameter. Meland (2009) observed that increase of apple tree yielding was related to a smaller percentage cover of the fruits with blush, which would indicate a positive effect of thinning on apple colouring. However, the results of this experiment do not support that opinion. Results from 2016 and the mean values for the two years did not indicate any significant reduction in the level of colouring under the effect of thinning. Whereas, in 2017, fruits from trees treated with Brevis $1.1 \mathrm{~kg}$ and MaxCel/Brevis were notably less coloured than the control fruits.

Certain researchers noted that after the application of benzyladenine, even if it did not produce the effect of thinning, apples were characterised by higher values of such quality parameters as the content of extract and flesh firmness (Greene et al. 1990). In this study, estimation of apples in terms of flesh firmness in 2016 showed a significant increase of its value after the application of Brevis $1.1 \mathrm{~kg}$ and MaxCel 51 (Tab. 3).

Table 3. Effect of various methods of thinning on internal quality parameters of apples cv. 'Braeburn Mariri Red'

\begin{tabular}{|c|c|c|c|c|c|c|c|}
\hline & Control & $\begin{array}{c}\text { Thinning by } \\
\text { hand }\end{array}$ & $\begin{array}{l}\text { Brevis } \\
1.1 \mathrm{~kg}\end{array}$ & MaxCel 51 & $\begin{array}{c}\text { MaxCel } \\
7.51 \\
\end{array}$ & $\begin{array}{l}\text { MaxCel } \\
+ \text { Brevis }\end{array}$ & $\begin{array}{c}\text { Mean for } \\
\text { a year }\end{array}$ \\
\hline $\begin{array}{l}\text { fruit firmness } 2016 \\
\left(\mathrm{kG} \mathrm{cm}^{-2}\right)\end{array}$ & $9.69 \mathrm{ab}^{*}$ & $9.88 \mathrm{a}-\mathrm{c}$ & $10.67 \mathrm{~d}$ & $10.33 \mathrm{~cd}$ & $9.45 \mathrm{a}$ & $10.01 \mathrm{bc}$ & $10.01 \mathrm{~A}^{* *}$ \\
\hline $\begin{array}{l}\text { fruit firmness } 2017(\mathrm{kG} \\
\left.\mathrm{cm}^{-2}\right)\end{array}$ & $10.71 \mathrm{bc}$ & $10.71 \mathrm{bc}$ & $10.51 \mathrm{ab}$ & $10.48 \mathrm{ab}$ & $10.27 \mathrm{a}$ & $10.96 \mathrm{c}$ & $10.61 \mathrm{~B}$ \\
\hline $\begin{array}{l}\text { fruit firmness } \\
\text { (mean for two years) }\end{array}$ & $10.20 \mathrm{~b}$ & $10.29 \mathrm{bc}$ & $10.59 \mathrm{c}$ & $10.40 \mathrm{bc}$ & $9.86 \mathrm{a}$ & $10.49 \mathrm{bc}$ & \\
\hline $\begin{array}{l}\text { extract content } \\
2016(\%)\end{array}$ & $11.55 \mathrm{a}$ & $11.65 \mathrm{a}$ & $12.85 \mathrm{ab}$ & $12.35 \mathrm{ab}$ & $12.35 \mathrm{ab}$ & $13.50 \mathrm{~b}$ & $12.38 \mathrm{~A}$ \\
\hline $\begin{array}{l}\text { extract content } \\
2017(\%)\end{array}$ & $12.17 \mathrm{ab}$ & $12.69 \mathrm{c}$ & $12.51 \mathrm{bc}$ & $11.95 \mathrm{a}$ & $12.44 \mathrm{a}-\mathrm{c}$ & $12.33 \mathrm{a}-\mathrm{c}$ & $12.35 \mathrm{~A}$ \\
\hline $\begin{array}{l}\text { extract content } \\
\text { (mean for two years) }\end{array}$ & $11.86 \mathrm{a}$ & $12.17 \mathrm{ab}$ & $12.68 \mathrm{~b}$ & $12.15 \mathrm{ab}$ & $12.40 \mathrm{ab}$ & $12.92 \mathrm{~b}$ & \\
\hline $\begin{array}{l}\text { dry matter content } 2016 \\
(\%)\end{array}$ & $15.41 \mathrm{~b}$ & $15.01 \mathrm{a}$ & $16.12 \mathrm{c}$ & $15.45 \mathrm{~b}$ & $15.29 \mathrm{ab}$ & $16.31 \mathrm{c}$ & $15.60 \mathrm{~A}$ \\
\hline $\begin{array}{l}\text { dry matter content } \\
2017(\%)\end{array}$ & $16.30 \mathrm{a}$ & $16.85 \mathrm{ab}$ & $16.52 \mathrm{ab}$ & $17.06 \mathrm{~b}$ & $16.62 \mathrm{ab}$ & $16.85 \mathrm{ab}$ & $16.70 \mathrm{~B}$ \\
\hline $\begin{array}{l}\text { dry matter content } \\
\text { (mean for two years) }\end{array}$ & $15.86 \mathrm{a}$ & $15.93 \mathrm{a}$ & $16.32 \mathrm{ab}$ & $16.25 \mathrm{ab}$ & $15.95 \mathrm{a}$ & $16.58 \mathrm{~b}$ & \\
\hline
\end{tabular}

*mean values in a column, denoted with the same lower-case letter, do not differ statistically at significance level $\mathrm{P}<0.05 ; * *$ mean values in a line, relating to a given parameter, denoted with the same capital letter, do not differ statistically at significance level $\mathrm{P}<0.05$.

In the following season, no significant increase of flesh firmness was observed, and apples from trees treated with MaxCel 7.51 were characterised by significantly lower flesh firmness than the control apples. Based on the mean values for the two years it was found that apples from trees treated with Brevis $1.1 \mathrm{~kg}$ had significantly higher flesh firmness, while after the application of MaxCel 7.51 its value was notably lower, relative to the control. Apple flesh firmness is a highly important property that determines acceptance by consumers (Jaeger et al. 1998). It is closely correlated with flesh crunchiness and juiciness, and inversely with flesh mealiness. Mehinagic et al. (2006) used a penetrometer to test the value of force required for point-wise penetration of 
apple flesh to the depth of $10 \mathrm{~mm}$ and found that apples cv. 'Braeburn' were characterised by the highest values of firmness relative to the highly popular cultivars 'Golden Delicious' and 'Fuji', both at the moment of harvest and after a period of storage.

In 2016, the content of extract was at a stable level and only fruits from trees treated with MaxCel/Brevis had higher values of that parameter. In the following season, apples from trees thinned by hand were characterised by significantly higher values of that parameter relative to the control. Based on the mean values for the two years of the study, it was determined that fruits from trees treated with Brevis $1.1 \mathrm{~kg}$ and $\mathrm{MaxCel} /$ Brevis were characterised by considerably higher values of extract content relative to the control.

In 2016, dry matter content after the application of Brevis $1.1 \mathrm{~kg}$ and MaxCel/ Brevis was significantly higher relative to the control, while after thinning by hand a significant decrease was noted in the value of that parameter. In the next season, apples were characterised by a fairly uniform content of dry matter, and only after the application of trees with MaxCel 51 caused a significant increase in the values of that parameter relative to the control. Based on the mean values for the two years of the experiment, it was observed that only the application of MaxCel/Brevis caused a significant increase of dry matter content relative to the control.

Combined spraying with two preparations often results in very strong thinning. Multiple applications of preparations or their mixtures are sometimes used to achieve a satisfactory level of fruitlet thinning, in situations when a one-time application of thinners at a given dose is insufficient (Wertheim 1998, Gabardo et al. 2017). In this experiment, combined application of the preparations MaxCel/Brevis produced the best thinning effects through a distinct decrease of yield and improvement of most of the analysed quality parameters of apples, relative to the control. Also Radivojevic et al. (2019) demonstrated that the use of a mixture of BA and metamitron can alleviate the unfavourable effect of low temperatures (below $10^{\circ} \mathrm{C}$ by night and below $20^{\circ} \mathrm{C}$ in daytime). The application of that mixture caused a significant increase in fruit dimensions and an improvement of yield structure.

\section{CONCLUSIONS}

Apple trees cv. 'Braeburn Mariri Red' can be successfully cultivated in the conditions of south-east Poland, but fruitlet thinning is necessary to obtain fruits of high quality. The effects of thinning depend on the weather conditions in a given season and on the condition of the trees. Each of the thinning methods used in the study caused a significant improvement of fruit size relative to the control. Only the application of MaxCel at the lower dose of $51 \mathrm{ha}^{-1}$ proved to be completely ineffective in both seasons of the study, due to a lack of improvement of yield structure, fruit mass, 
and also fruit diameter and height. The application of Brevis $1.1 \mathrm{~kg} \mathrm{ha}^{-1}$ and MaxCel $7.51 \mathrm{ha}^{-1}$ caused comparable effects on yield level and structure, but apples from trees treated with Brevis $1.1 \mathrm{~kg} \mathrm{ha}^{-1}$ were characterised by notably higher flesh firmness.

The best effects of thinning were noted after the combined application of the preparation MaxCel/Brevis, as the yield was considerably lower than in the control treatment, and the fruits were characterised by the highest values of the analysed quality parameters: fruit mass, diameter, height, content of extract and of dry matter.

Conflict of interest: The Authors does not declare conflict of interest.

\section{REFERENCES}

Bound S.A., Jones K.M., Oakford M.J., 1997. Post-bloom thinning with 6-benzyladenine. Acta Hortic., 463, 493-499, https://doi.org/10.17660/ActaHortic.1998.463.62

Bubán T., 2000. The use of benzyladenine in orchard fruit growing: a mini review. Plant Growth Regulation, 32, 381-390, https://doi.org/10.1023/A:1010785604339

Buszard D.J., Schwabe W.W., 1995. Effect of previous crop load on stigmatic morphology of apple flowers. J. Amer. Soc. Hort. Sci., 120, 4, 566-570, https://doi.org/10.21273/JASHS.120.4.566

Byers R.E., 2002. Influence of temperature and darkness on apple fruit abscission and chemical thinning. J. Tree Fruit Prod., 3(1), 41-52, https://doi.org/10.1300/J072v03n01_04

De Salvador F.R., Fisichella M., Fontanari M., 2006. Correlation between fruit size and fruit quality in Apple trees with high and standard crop load levels. J. Fruit Ornam. Plant. Res., 14, 113-122.

Elfving D.C., Cline, R.A., 1993. Benzyladenine and other chemicals for thinning 'Empire' apple trees. J. Am. Soc. Hortic. Sci., 118(5), 593-598, https://doi.org/10.21273/JASHS.118.5.593

Ferree D.C., 1996. Performance of benzyladenine as a chemical thinner on eight apple cultivars. J. Tree Fruit Prod., 1, 33-50, https://doi.org/10.1300/J072v01n02_03

Gabardo G.C., Petri J.L., Hawerroth T.J., Couto M., Argenta L.C., Kretzschmar A.A., 2017. Use of metamitron as an apple thinner. Rev. Bras. Frutic., 39(3), e-514, https://doi.org/10.1590/ 0100-29452017514

Greene D.W., 1993. A review of the use of benzyladenine (BA) as a chemical thinner for apples. Acta Hortic., 329, 231-236, https://doi.org/10.17660/ActaHortic.1993.329.50

Greene D.W., 2002. Chemicals, timing and environmental factors involved in thinner efficacy on apple. Hort. Sci., 37, 477-481, https://doi.org/10.21273/HORTSCI.37.3.477

Greene D.W., 2005. Effects of repeated yearly application of chemical thinners on 'McIntosh' apples. Hort. Sci., 40, 401-403, https://doi.org/10.21273/HORTSCI.40.2.401

Greene D.W., Antio W.R., Miller P., 1990. Thinning activity of benzyladenine on several apple cultivars. Hort. Sci., 117(5), 775-779.

Jaeger S.R., Andani Z., Wakeling I.N., MacFie H.J.H., 1998. Consumer preferences for fresh and aged apples: a cross-cultural comparison. Food Qual. Pref., 9(5), 355-366, https://doi.org/10.1016/ S0950-3293(98)00031-7

Link H., 2000. Significance of flower and fruit thinning on fruit quality. Plant Growth Regul., 31, 17-26, https://doi.org/10.1023/A:1006334110068

McArtney S.J., Obermiller J.D., 2014. Use of shading and psII inhibitor metamitron to investigate the relationship between carbohydrate balance and chemical thinner activity in apples. Acta Hortic., 1042, 27-31, https://doi.org/10.17660/ActaHortic.2014.1042.2 
McLaughlin J.M., Greene D.W., 1984. Effects of BA, GA4+7and daminozide on fruit set, fruit quality, vegetative growth, flower initiation and flower quality of 'Golden Delicious' apples. Hortic. Sci., 109, 34-39.

Mehinagic E., Royer G., Symoneaux R., Jourjon F., 2006. Relationship between Apple sensory attributes and instrumental parameters of texture. J. Fruit Ornam. Plant Res., 14(2), 25-37.

Meland M., 2009. Effects of different crop loads and thinning practices on yield, fruit quality and return bloom in Malus x domestica Borkh. 'Elstar'. J. Hortic. Sci. Biotech., 84(6), 117-121, https://doi.org/10.1080/14620316.2009.11512607

Olien W.C., Bukovac M.J., 1971. Factors influencing the penetration of napthaleneacetamide into leaves of pear (Pyrus communis L.) J. Amer. Soc. Hort. Sci., 96, 240-246.

Palmer J.W., Giuliani R., Adams H.M., 1997. Effect of crop load on fruiting and leaf photosynthesis of 'Braeburn'/M26 apples trees. Tree Physiol., 17(11), 741-746, https://doi.org/10.1093/ treephys/17.11.741

Radivojevic D., Milivojevic J., Pavlovic M., Stopar M., 2019. Comparison of metamitron efficiency for postbloom thinning of 'Gala' and 'Golden Delicious' young apple trees. Turk. J. Agric. For., $43,1-12$

Schwabe W.W., 1978. Growth regulators and the control of development in fruit trees. British Crop Protection Monogr., 21, 143-157.

Telias A., Lin-Wang K., Stevenson D., Cooney J., Hellens R., Allan A., Hoover E., Brodeen J., 2011. Apple skin pattering is associated with differential expression of MYB10. BMC Plant Biol., 11, 93, https://doi.org/10.1186/1471-2229-11-93

Wertheim S.J. 1998. Chemical thinning of deciduous fruit trees. Acta Hortic., 463, 445-462, https:// doi.org/10.17660/ActaHortic.1998.463.57

Williams M.W., 1994. Factors influencing chemical thinning and update on new chemical thinning agents. Compact Fruit Tree, 27: 115-122.

Wismer P.T., Proctor J.T.A., 1995. Benzyladenine affects cell division and cell size during apple fruit thinning. J. Am. Soc. Hortic. Sci., 120(5), 802-807, https://doi.org/10.21273/JASHS.120.5.802

Wünsche J.N., Ferguson I.B., 2005. Crop load interaction in Apple. Hort Rev., 31, 231-290, https:// doi.org/10.1002/9780470650882.ch5.

Wünsche J.N., Palmer J.W. Greer D.H., 2000. Effects of crop load on fruiting and gas-exchange characteristics of 'Braeburn'/M26 apple trees at full canopy. J. Am. Soc. Horticul. Sci., 125(1), 93-99, https://doi.org/10.21273/JASHS.125.1.93 